\title{
Water quality as bio-cultural screening indicator for the integrity of informal heritage sites
}

\author{
S Cawood' and AT Vos ${ }^{2 *}$ \\ 'Centre for Africa Studies, University of the Free State, PO Box 339, Bloemfontein, 9300, South Africa \\ ${ }^{2}$ Centre for Environmental Management, University of the Free State, PO Box 339, Bloemfontein, 9300, South Africa
}

\begin{abstract}
At informal heritage sites, a complex mutually-detrimental interaction or 'cycle of risk' between human, animal and ecological risk factors was detected where water quality is representative of ecological risk and cultural practices associated with the heritage intrinsic to sites are indicative of human risk. Informal heritage sites are therefore especially vulnerable as they are actively utilised, but not formally protected or sustainably managed. In South Africa, biomonitoring methods are used nationally for a rapid assessment of aquatic ecosystem health, subsuming a number of index models. There are six index models wherein water quality is ensconced. Of these the Physico-chemical Driver Assessment Index (PAI) is more complex and comprehensive than the others and therefore not conventionally the most rapid application. In addition, the Health Impact Assessment (HIA) was developed recently to measure the community health of people. Despite its complexity, water quality as part of the PAI was found to be the most appropriate of the available biomonitoring indices and, in this context, the most productive indicator for the cultural heritage-ecology interaction at informal heritage sites. This is based on the fact that potable water is such a fundamental human need and intricately interwoven with ritual cultural practice. The objective of the study was therefore to propose a biomonitoring model to explore the integrity of informal heritage sites where integrity encapsulates the environmental health and the authenticity of cultural practice as heritage. The authors conceived a 'bio-cultural screening' model and explored water quality as primary indicator, where water quality comprises biological (algal, bacterial), chemical (oxygen, $\mathrm{pH}$, TDS, phosphorus, nitrogen, carbon, chlorophyll-a) and physical (temperature, turbidity) analyses. This method is then put forward as the Rapid Integrity Appraisal (RIA) for informal heritage sites, which may lead to the further application of other biomonitoring indices to these sites should a more nuanced exploration of the integrity of specific sites be required.
\end{abstract}

Keywords: biomonitoring, water quality, bacterial pollution, Rapid Integrity Appraisal, heritage, informallydeclared heritage sites.

\section{INTRODUCTION}

This article follows on a previous article by Vos and Cawood (2010) that postulated the extrapolating power of water quality as an indicator for the health of informal heritage sites. In the National Heritage Resources Act (No. 25 of 1999; RSA, 1999), a heritage site conventionally refers to a 'place declared as a national heritage site by the South African Heritage Resources Agency or a place declared as a provincial heritage site by a provincial heritage resources agency. This means that in terms of the National Heritage Resources Act, only places that have successfully progressed through the legal process related to declaration are defined as heritage sites under the Act.

In order to differentiate between sites of heritage significance that are declared and sites of heritage significance that are not declared, these are respectively designated as formal heritage sites (declared) and informal heritage sites (not declared). Formal heritage sites at local, provincial and national level are subject to conservation and management protocols of varying rigour but, by and large, are protected under the National Heritage Resources Act. However, one of the major challenges faced by informal heritage resources, including sites used for religio-spiritual, cultural or tourism purposes, is environmental degradation which could ultimately lead to risks to human health and the heritage embedded in those spaces. Consequently,

\footnotetext{
* To whom all correspondence should be addressed.

× +7251 401 3959/2863; e-mail: VosAT@ufs.ac.za

Received 4 September 2015; accepted in revised form 6 September 2016
}

there is a direct link between environmental conditions and the integrity of heritage at informal heritage sites.

The fact that certain heritage sites may not be formally declared or managed is in no way indicative of a lesser cultural, religious or economic value, but may be more a function of the complexity and cost outlay of a formal declaration procedure. The question that arises from this is what to do with informal heritage sites that fall outside any formal protection protocol? How can site integrity be expediently and cost-effectively monitored by researchers or heritage practitioners in order to improve its management?

During 2009-2010, physical, chemical and biological water quality measurements were done at the informal heritage sites of Mautse, a sacred valley, and Motouleng, a sacred cave, in the Eastern Free State, as part of the National Heritage Council (NHC) Project (Cawood, 2010). Both sites are shrines in a vibrant pilgrimage movement throughout the Caledon or Mohakare Valley. The findings indicated that turbidity and bacterial analysis, specifically Escherichia coli (E. coli) concentrations as an indicator of faecal pollution, were the most valuable measurements for gauging the integrity of informal heritage sites. Based on these findings, the authors adapted and streamlined existent biomonitoring strategies of aquatic ecosystems for application to informal heritage sites into a diagnostic tool called the Rapid Integrity Appraisal (RIA), which is part of a broader contingency action cycle that is activated where intervention appears necessary.

In this article, the material and methods applied over the 2 years of fieldwork are first discussed as well as the findings, 
followed by a discussion of the application of RIA to informal heritage sites.

\section{MATERIALS AND METHODS}

\section{Study sites}

The two study sites that were selected expand on the investigation at the two heritage sites explored in the previous study, Mautse $\left(28.66228^{\circ} \mathrm{S} ; 28.00902^{\circ} \mathrm{E}\right)$ and Motouleng $\left(28.57998^{\circ} \mathrm{S}\right.$ $28.38059^{\circ} \mathrm{E}$ ) (Fig. 1). The turnoff to Mautse ( $8 \mathrm{~km}$ gravel road) is found $19 \mathrm{~km}$ on the Rosendal road turnoff (R70) from Ficksburg in the eastern Free State. At Mautse (Fig. 2), the various sites of cultural significance (CS) are scattered throughout the surrounding valley. Five sampling sites (Mal -5$)$ were chosen in two of the streams in the valley with an average depth of around 10 to $20 \mathrm{~cm}$, consisting mostly of bedrock as substrate. The sampling streams, with others, form part of the small headwater streams of the Moolmanspruit. Tempeleng (MaCS1), is considered to be particularly sacred, and is situated alongside one of the streams below an overhang. With high water levels, the stream forms a waterfall into a large pool where baptism, healing and purification rituals take place, particularly during mainstream religious holidays such as Easter, as well as during traditional initiation rites. The researchers also witnessed the use of the sacred pool for household and sanitation purposes (Vos and Cawood, 2010).

The turnoff to Motouleng ( $5 \mathrm{~km}$ of gravel farm road) is found at Surrender Hill, $14 \mathrm{~km}$ from Clarens on the road to Fouriesburg (R711). At Motouleng (Fig. 3), the various sites of CS pertaining to the current study are concentrated in the small area of the cave. Here, three sampling sites (Mo1 to 3) were chosen on the Little Caledon River that flows past the cave with an average depth around 30 to $60 \mathrm{~cm}$. The Little Caledon substrate consists of a mixture of bedrock, boulders, cobble, gravel and sand. Sampling began upstream from the cave and ended downstream near the parking area. The Little Caledon River transects agricultural land upstream and downstream of the site (Vos and Cawood, 2010).

\section{Methods}

During June, August, and October 2009, and February 2010, the following measurements were taken at each site: water temperature $\left({ }^{\circ} \mathrm{C}\right)$, concentration of dissolved oxygen $(\mathrm{mg} / \mathrm{L})$, and percentage saturation $\left(\mathrm{O}_{2} \%\right)$ were measured in situ with an YSI Model 85 oxygen, conductivity, salinity, temperature meter. The $\mathrm{pH}$ was measured in situ with a Eutech Instruments CyberScan $\mathrm{pH} 110$ meter $\left(\mathrm{pH} / \mathrm{mV} /{ }^{\circ} \mathrm{C} /{ }^{\circ} \mathrm{F}\right.$ with RS232). A handheld GPS (Garmin: eTrex Vista Personal Navigator GPS) was used to record the locations of the sampling points.

As described in Vos and Cawood (2010), subsurface grab samples ( $2 \mathrm{~L}$ ) were taken on the sampling dates from the river shore and brought to the different laboratories for further physi$\mathrm{cal}$, chemical and biological analyses. All the samples were kept on ice and stored in a refrigerator $\left(\leq 5\right.$ to $\left.0^{\circ} \mathrm{C}\right)$ until analyses could be done by the various laboratories.

Turbidity (clarity), a suspended solid measurement, was determined with an Aqua Lytic Turbidimeter AL 1000 in a laboratory (expressed as Nephelometric Turbidity Unit (NTU)).

Dissolved reactive ortho-phosphate $\left(\mathrm{PO}_{4}-\mathrm{P}\right)$ was determined using the stannous chloride method as described in Standard Methods (APHA, 2005). A Beijing Rayleigh Analytical Instrument Corp. VIS-7220 spectrophotometer was used.

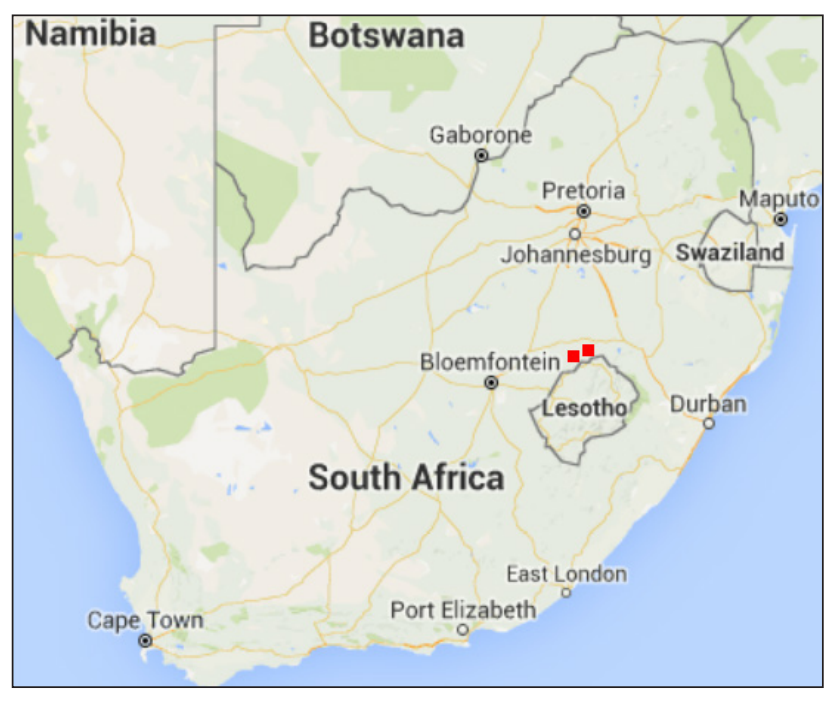

Figure 1

The location of Mautse and Motouleng within South Africa (shown as red dots; source: Google Maps, 2015)

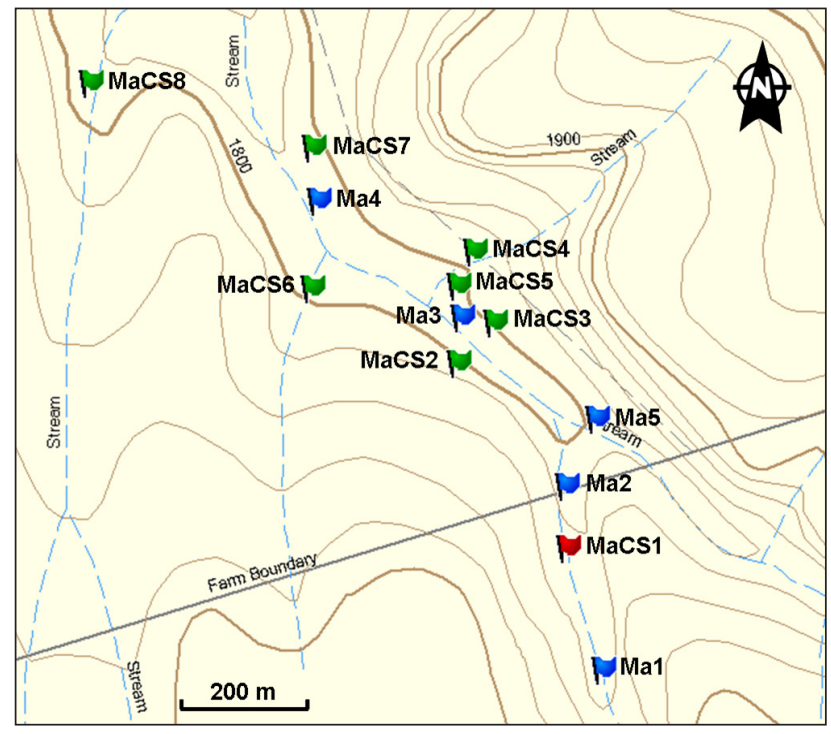

Figure 2

Topographical map (Department of Rural Development and Land Reform, Chief Directorate: Surveys and Mapping) showing the sampling sites (Ma) and the sites of cultural significance (CS) at Mautse. Site legend: Water sampling sites (blue flag): Above Tempeleng (Ma1), Below Tempeleng (Ma2), Below Yunivesithi (Ma3), Downstream of Monica's (Ma4), and Diepsloot (Ma5). CS sites (red/green flag): Tempeleng (MaCS1), Masiheng (MaCS3), Yunivesithi (MaCS5), and Monica's (MaCS6) (Vos and Cawood, 2010).

The Institute for Groundwater Studies (IGS) at the University of the Free State used a Perkin Elmer Optima 300 DV Inductively Coupled Plasma (ICP) Spectrometer to measure the concentration of the following salts: calcium $\left(\mathrm{Ca}^{2+}\right)$, chloride $\left(\mathrm{Cl}^{1-}\right)$, magnesium $\left(\mathrm{Mg}^{2+}\right)$, alkalinity (p-alk and $\mathrm{m}$-alk), potassium $\left(\mathrm{K}^{1+}\right)$, sodium $\left(\mathrm{Na}^{1+}\right)$, sulphate $\left(\mathrm{SO}_{4}^{2-}\right)$, ammonium-nitrogen $\left(\mathrm{NH}_{4}-\mathrm{N}\right)$, nitrate-nitrogen $\left(\mathrm{NO}_{3}-\mathrm{N}\right)$, and phosphate $\left(\mathrm{PO}_{4}^{2-}\right)$. All of the above were included in the calculation of total dissolved salts (TDS); $\mathrm{NH}_{4}-\mathrm{N}$ plus $\mathrm{NO}_{3}-\mathrm{N}$ was combined for the dissolved inorganic nitrogen (DIN), and $\mathrm{PO}_{4}{ }^{2+}$ was used for dissolved inorganic phosphorus (DIP). The total nitrogen (TN) and total phosphates (TP) were measured by the Institute for Groundwater Studies (IGS) using an ICP Spectrometer. 


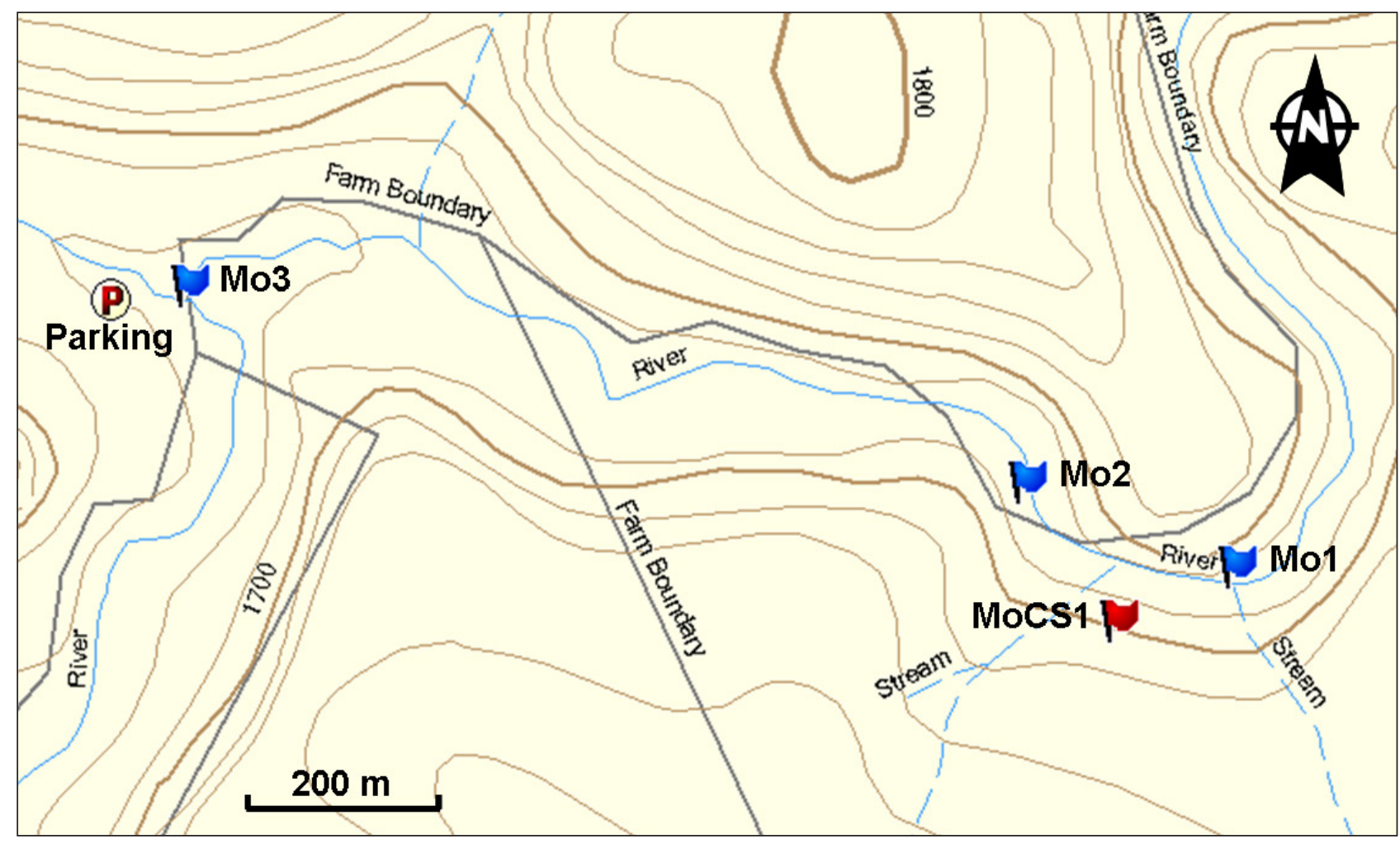

Figure 3

Topographical map (Department of Rural Development and Land Reform, Chief Directorate: Surveys and Mapping) showing the sampling sites (Mo) and the sites of cultural significance (CS) at Motouleng. Site legend: water sampling sites (blue flag) - Upstream of Cave (Mo1), Downstream of Cave (Mo2), and Near Parking (Mo3). CS sites (red/green flag) - Cave (MoCS1) (Vos and Cawood, 2010).

Bacterial grab samples for the analysis of E. coli were taken in sterile glass bottles; concentrations were determined by the IGS, according to the IDEXX Colilert-18 Method (IDEXX, 2015). Concentrations were expressed as MPN/100 mL and were converted to cfu/100 mL by IGS, for comparison with South African Water Quality Guidelines.

A modified method described by Sartory and Grobbelaar (1984) was used to measure Chlorophyll- $a$ utilising a VIS-7220 spectrophotometer. The identification and enumeration of algal species was done with an inverted Zeiss Light Microscope after fixation with formaldehyde (final concentration of $2 \%$ ) and stored in a sedimentation chamber for at least $24 \mathrm{~h}$, according to the Utermöl method (Wetzel and Likens, 1991).

Rainfall data for the Clarens and Ficksburg areas (2009-2010) were obtained from the South African Weather Service (SAWS, n.d.)

All results are based on 4 samples per sampling location at the 2 sacred sites, taken during 2009 to 2010 . The samples from each sampling location were treated as separate data sets, which comprise only 4 measurements. Two sites at Mautse, Above Tempeleng (Ma1) and Diepsloot (Ma5), were not sampled during June 2009; they were added later in the study to specifically gauge the impact of Tempeleng. During the February 2010 sampling, rain inhibited (slippery steep sandstone rock faces) sampling at Above Tempeleng (Ma1).

\section{RESULTS AND DISCUSSION}

\section{Application of biomonitoring to informal heritage sites}

Biological monitoring or biomonitoring, as it is known today, can be traced globally to before the 1950s (Chutter, 1972; Dickens and Graham, 1998). The biomonitoring context specifically germane to this matter is the biomonitoring of aquatic ecosystems. In South Africa in the 1970s, Chutter began looking at the biomonitoring of South African rivers and streams, with particular focus on macro-invertebrates as indicators of aquatic health (Chutter, 1994).

Since then, numerous indices have been developed, and the River Health Programme (RHP) was established in the early 1990s (Bate et al., 2002), which was replaced by the River Ecostatus Monitoring Programme (REMP) in 2016 (DWS, 2016). The indices in use today have been continually refined since the inception of the RHP and the new REMP, and comprise of the following:

- MIRAI (Macro-Invertebrate Response Assessment Index; Thirion, 2007);

- FRAI (Fish Response Assessment Index; Kleynhans, 2007);

- VEGRAI (Riparian Vegetation Response Assessment Index; Kleynhans et al., 2007);

- PAI (Physico-Chemical Driver Assessment Index; Kleynhans et al., 2005);

- GAI (Geo-Morphological Driver Assessment Index; Rowntree, 2013).

Conventionally, a biomonitoring process would begin with the Index for Habitat Integrity (IHI; Kleynhans et al., 2009), which is basically a general observation of the environmental context.

In recent years a new approach was presented in the form of the Health Impact Assessment (HIA). The HIA estimates the effect that a specific action has on the health of a population and assesses potential health impacts (Bailey, 2010). Applying 
the principles of the different approaches to heritage sites, the authors conceptualised bio-cultural screening, which entails biomonitoring strategies specifically applied to assess the integrity of informal heritage sites that are not formally declared and therefore not managed or protected in any specific way.

Bio-cultural screening is specifically meant to form part of a broader contingency action cycle should the data point towards the need for intervention at specific sites, and is the first step in the cycle. The contingency action cycle comprises 4 recurrent steps (Fig. 4):

1. Diagnosis of the state of an informal heritage site through bio-cultural screening as diagnostic tool

2. Planning action steps: (prepare for provincial or national declaration; prepare for temporary declaration while the situation is further investigated; establish community forums as de facto 'managing boards')

3. Implementation of the action steps

4. Evaluating the outcome

After the evaluation step, the cycle begins again and continues.

\section{Water quality as Rapid Integrity Appraisal (RIA)}

Ideally, a complete bio-cultural screening model would include all existing bio-monitoring indices (Fig. 5). However, in a country such as South Africa with immense social challenges, the formal heritage sector is under-resourced. Resources are even scarcer for informal heritage management. This means that the full spectrum of biomonitoring indices simply cannot be justified for informal heritage sites. Therefore, in the specific context of limited resources in terms of time, expertise and funding, a pragmatic view has to be taken to rapidly and efficiently assess the integrity of informal sites. Because of the importance of human intervention in heritage, the authors have turned the convention of using biota and other drivers as the main indicators for ecological health on its head and deconstructed PAI to form the primary indicator of the bio-cultural screening model.

During the course of the actual NHC research project, the researchers found certain analyses related to water quality more valuable for extrapolation than others, namely, turbidity and bacterial analysis specific to $E$. coli. In the bio-cultural screening model, we have conceptualised these parameters as forming the Rapid Integrity Appraisal (RIA) module. The idea behind RIA was to find the most expedient and efficient mode to rapidly assess the integrity of a particular informal heritage site. The steps of the RIA are shown in more detail in Fig. 6.

RIA is not meant to be a comprehensive method, but is rather aimed at collecting baseline data for immediate decisionmaking and the possible implementation of a full water quality assessment, or perhaps a complete bio-cultural screening (Fig. 7). It can even lead to the implementation of the contingency action cycle (Fig. 4) should it be deemed necessary.

The RIA only consists of one physical parameter, turbidity, and the biological/bacterial parameter, E. coli. The choice of the biological/bacterial parameter is logical given the potential human impact. Although it may seem unusual, the researchers found turbidity a natural choice of parameter for RIA because of its value for extrapolation. Should turbidity be unusually high, RIA could be further extended to investigate its origin. The origins of turbidity could include massive loads of sediment, algae, or extreme $\mathrm{pH}$ levels. Should the particular informal heritage site require it, turbidity could be explored in further detail through
VEGRAI, GAI and HIA, but this will only happen on a case-bycase basis. Should algae be the cause of turbidity in a water body, researchers would need to ascertain the exact species, as certain algae excrete toxins. In cases of extreme $\mathrm{pH}$ levels where there are no industry or mines in the area, researchers may also extend RIA to include GAI to determine whether the phenomenon is a natural geological occurrence.

Although the RIA does not make use of all the physical, biological and chemical parameters measured during the course of the study, most of these will be discussed and the context with regard to RIA explained.

\section{Physical parameters}

For the water temperature there was a seasonal trend found at both sites, where the water temperature increased as the seasons moved from winter $\left( \pm 8^{\circ} \mathrm{C}\right)$ to summer $\left( \pm 20^{\circ} \mathrm{C}\right.$; Fig. 7$)$; this corresponded with the seasonal increase of atmospheric temperature (Walling and Webb, 1992). At Motouleng sampling sites $\mathrm{Mo} 1$ and $\mathrm{Mo} 2$ the water temperature did not increase from June to August 2009, but this could be ascribed to interflow springs that have low water temperatures. The mean water temperature at Mautse was $1^{\circ} \mathrm{C}$ warmer than at Motouleng. Water temperature can be useful as an indicator of thermal pollution or as a limiting factor for the growth of certain algal and fish species (Horne and Goldman, 1994). However, based on the measurements taken during this study and the range of temperature, it seemed as if the variations at the study sites are within the normal range and temperature was not a factor impacting the integrity of the ecological health of these sites and was therefore excluded from the RIA.

The dissolved oxygen concentrations (DO; Fig. 8a) at the two sites also showed a seasonal trend, but an inverse of the temperature trend. This can be expected as oxygen is more soluble in cooler water than in warmer water (Dallas and Day, 2004; Davies and Day, 1998). Apart from sampling site Ma4 (October 2010) at Mautse, all the other sampling sites (and samples) had a dissolved oxygen saturation level of above $50 \%$ which is favourable for aquatic biota and does not indicate any significant human impacts (Fig. 8b). The mean DO at Motouleng (9.4 mg/L; 86.9\%) was higher than at Mautse $(7.2 \mathrm{mg} / \mathrm{L} ; 70.4 \%)$, probably due to the fact that the Little Caledon River is bigger (wider and deeper) than the headwater stream (Moolmanspruit) that flows through Mautse, and also due to its lower water temperature. Since DO is largely subject to seasonal trends, extrapolation in terms of RIA was negligible and therefore omitted. From an economic standpoint, oxygen meters are fairly expensive and may not be accessible to local stakeholders.

The $\mathrm{pH}$ at Mautse ranged between 6.9 and 8.7, while at Motouleng it ranged between 7.7 and 8.9. The mean $\mathrm{pH}$ at Mautse was lower than at Motouleng (with a noticeable seasonal trend; Fig. 9). This also concurs with the notion that rivers in the eastern part of the country have a $\mathrm{pH}>7$ (Allanson, 1995). It is also likely that Motouleng has a better buffering capacity with its higher $\mathrm{pH}$ and DO concentrations (Dallas and Day, 2004). In general, the $\mathrm{pH}$ at both these sites was within the normal range and there is no reason to investigate possible sources of pollution that can impact on the $\mathrm{pH}$.

The turbidity (Fig. 10) at Mautse ranged from 0.6 to $3.7 \mathrm{NTU}$ (mean was 1.8 NTU) and at Motouleng from 2.0 to 28.0 NTU (Mean was 10.3 NTU). At Mautse, the bedrock substrate at the upper sampling sites (Ma1-3 and Ma5) could be the contributing factor for their lower turbidity (all means lower than 2 NTU) as there are no sedimentary particles to be suspended in the 


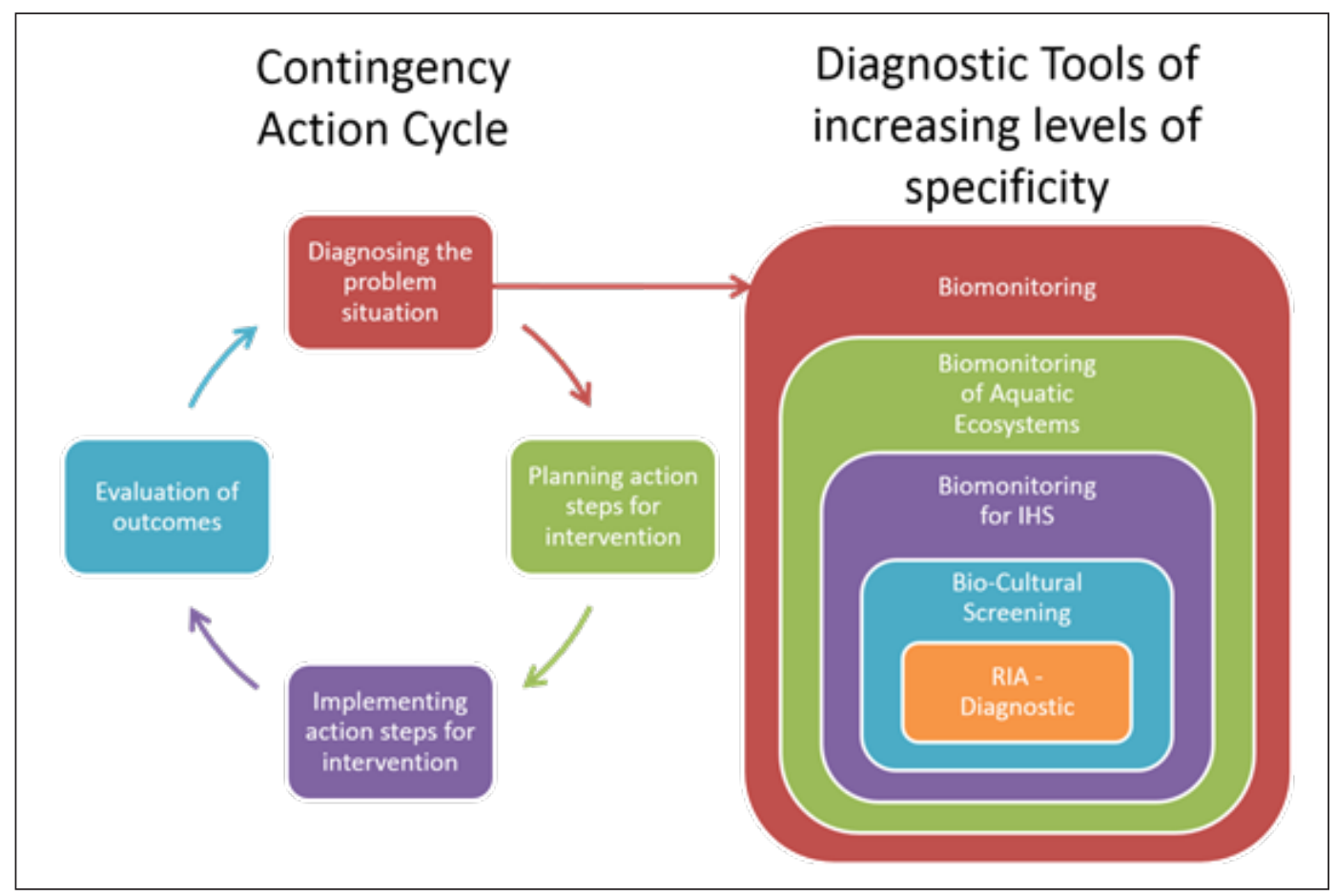

Figure 4

The contingency action cycle and diagnostic tools

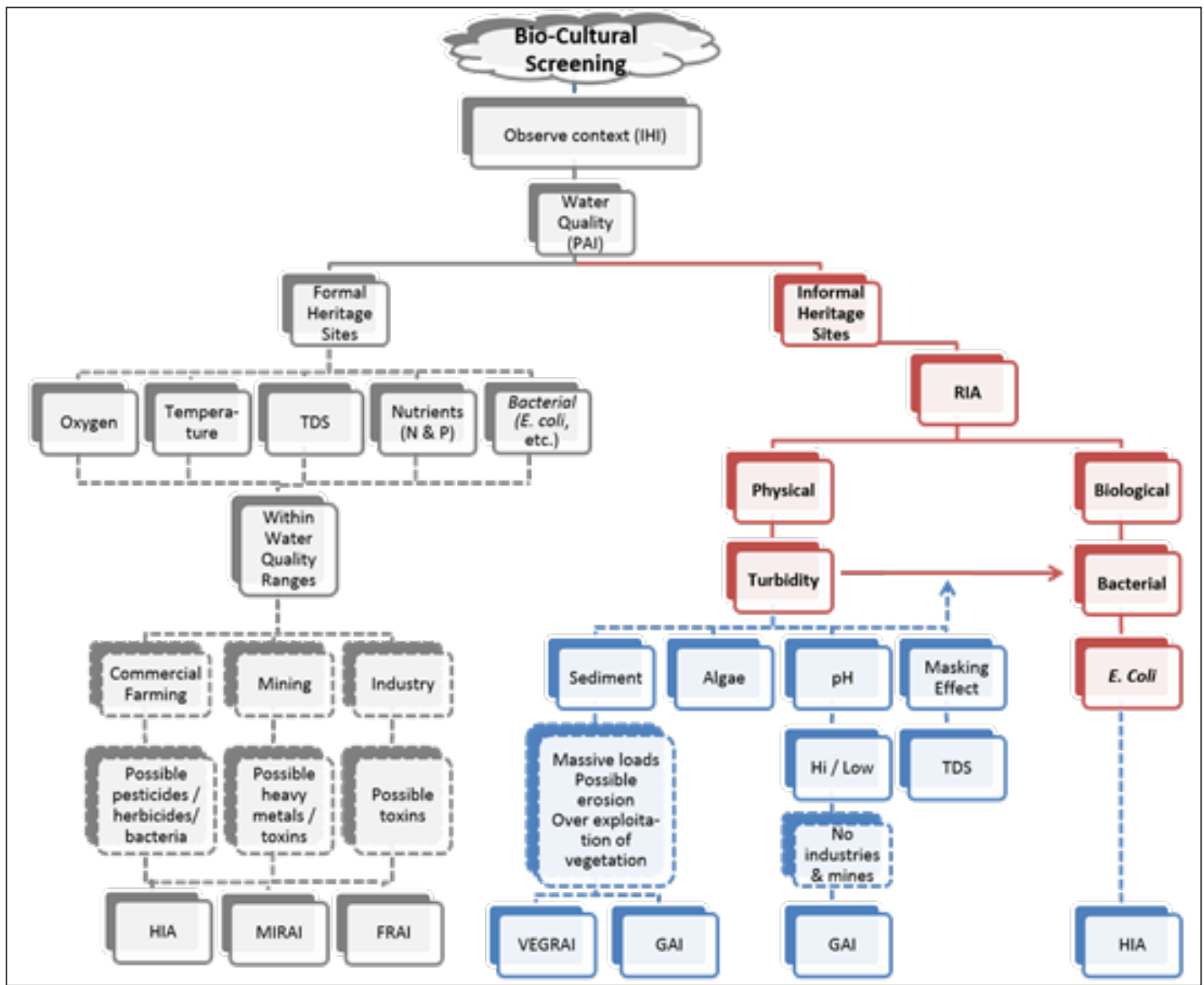

Figure 5

The complete bio-cultural screening model 
shallow water column, whereas some sand/gravel substrate at Ma4 accounts for the slightly higher turbidity at this site (mean slightly $>2$ NTU). The substrate at Motouleng mostly consists of sand/gravel and this contributes to its higher turbidity ( $>10 \mathrm{NTU}$ ). The turbidity is also influenced by rainfall. Over the total sampling period it was found that when it rained before the sampling (Fig. 11 and Table 1) the turbidity was higher than when not and the more it rained the higher the turbidity.

While the turbidity measurements were low during the whole of the study period, falling below the range of $<25$ NTU (DWAF, 1996a) for clear-water fish species; it did not guarantee potable water, as unacceptable bacterial loads were identified at both Mautse and Motouleng (Fig. 16). This may seem to render the possible impacts linked to the 'turbidity indicator' as limited, but the researchers argue that turbidity remains an important and rapid form of simple observation as an introductory step in RIA, when considered in relation to the presence of human activity in and around that water body. In cases where humans or animals are openly using water sources or the immediate environments for sanitation purposes and the particular water sources are visibly turbid, then one can reasonably extrapolate the presence of bacteria associated with faecal coliforms. Here, immediate steps should be taken to warn stakeholder communities of the possible aquatic health risk. In cases where such water sources appear clear, as in the case of Mautse where the substrate is mostly bedrock, further bacterial analysis becomes necessary as turbidity is then excluded due to a masking effect (Vos and Cawood, 2010). This means that at informal heritage sites with a lot of human cultural activity, clarity may not guarantee potable water (Vos and Cawood, 2010). In those cases turbidity provides no extrapolating potential and cannot be used as indicator for water quality, although this does not apply universally. Therefore, turbidity was included in RIA as the first and simplest point of entry.

\section{Chemical parameters}

Chemical parameters were measured to investigate the possible impacts at these sites for possible use in RIA. The total dissolved salts concentrations (TDS; Fig. 12) at both Mautse's and Motouleng's sampling sites were approximately $300 \mathrm{mg} / \mathrm{L}$ or lower. The TDS also showed a relation to the rainfall similar to the turbidity, whereby it decreased after rain. The rainwater probably acted as diluting agent to the salts already in the stream/river water. An inverse relationship therefore also exists between total dissolved salts (TDS) concentrations and turbidity where an increase in TDS leads to a decrease in turbidity (Roos and Pieterse, 1995). According to Allanson (1995), the natural surface water in this area has a TDS concentration that falls below $300 \mathrm{mg} / \mathrm{L}$, therefore placing the TDS concentrations within the natural range, with no further investigation required.

The dissolved inorganic phosphorus (DIP; Fig. 13a) at Mautse did not show a very distinct pattern other than that all sampling sites either August of October 2009 had the highest concentrations and February 2010 the lowest concentrations. Part of this pattern was also observed for total phosphorus (TP; Fig. 13b), where the concentrations of either August or October 2009 were the highest (TP concentrations could not be analysed lower than $0.1 \mathrm{mg} / \mathrm{L}$ ). At Motouleng the DIP concentrations of October 2009 were the highest at all sampling sites (Mo 1 - Mo3) with that of February the lowest. The TP concentrations were highest during June 2009.

It is thought that the DIP concentrations at sampling sites $\mathrm{Ma} 1$ and Ma5 to be due to natural influences, since no or little

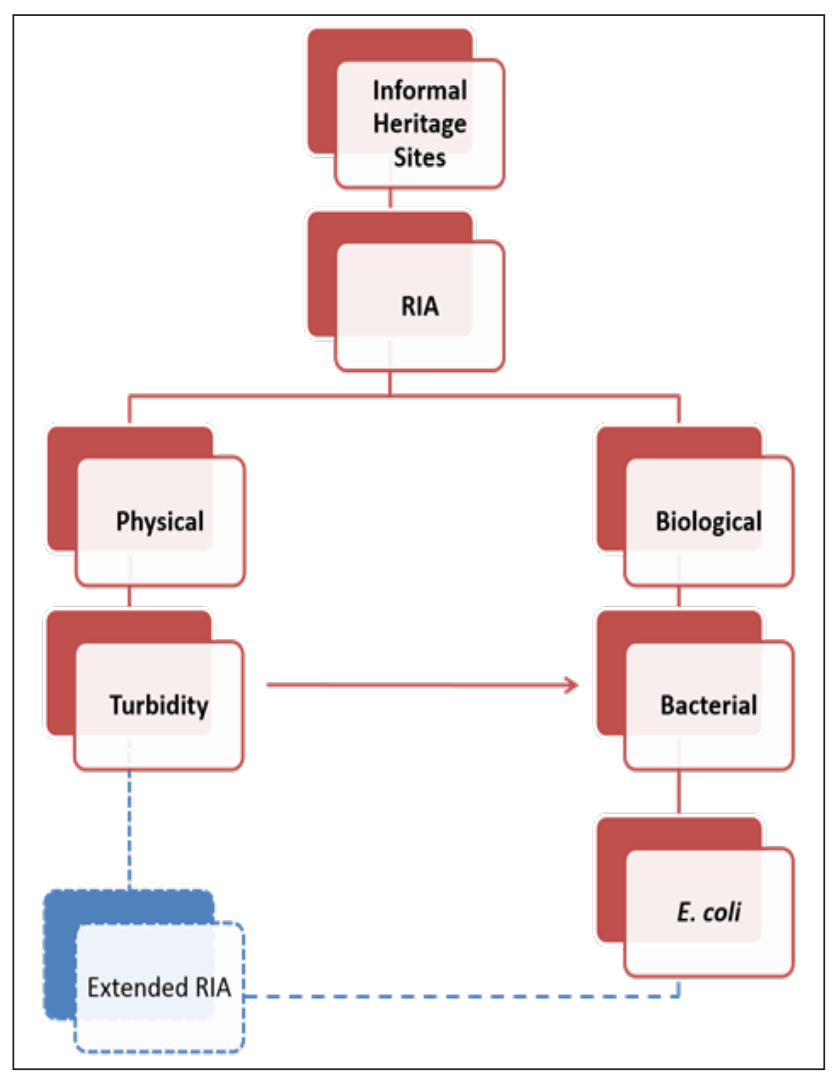

Figure 6

The Rapid Integrity Appraisal as bio-cultural screening module

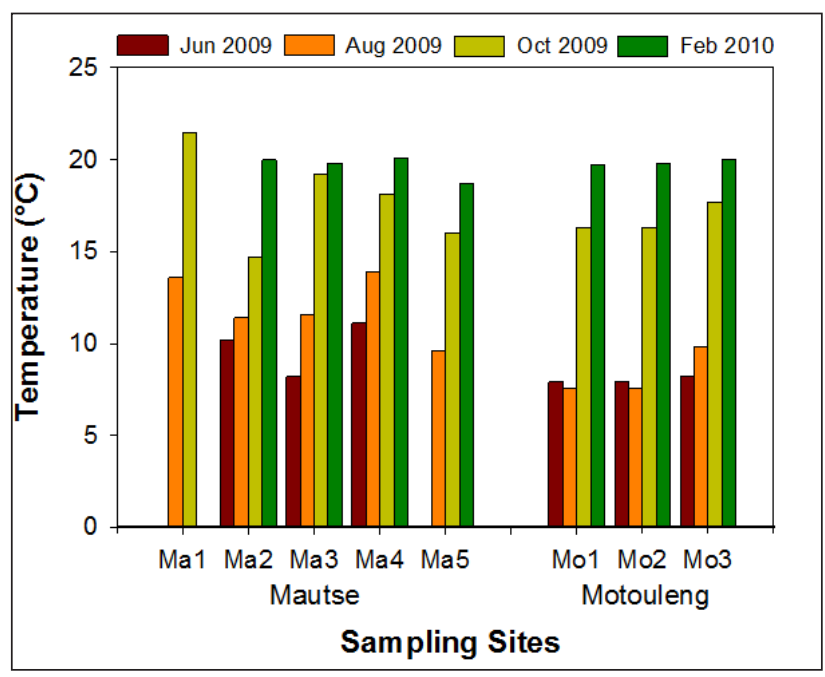

Figure 7

Temperature at the sampling sites at Mautse and Motouleng for June, August and October 2009, and February 2010

TABLE 1

Rainfall in the Ficksburg (Mautse) and Clarens (Motouleng) area for up to $\mathbf{1 4}$ days prior to each sampling date (SAWS, n.d.)

\begin{tabular}{|l|c|c|}
\hline \multirow{2}{*}{ Sampling date } & \multicolumn{2}{|c|}{ Rainfall $(\mathrm{mm})$} \\
\cline { 2 - 3 } & Ficksburg & Clarens \\
\hline June 2009 & 0 & 8 \\
\hline August 2009 & 0 & 0 \\
\hline October 2009 & 50.5 & 28.5 \\
\hline February 2010 & 55.8 & 116 \\
\hline
\end{tabular}




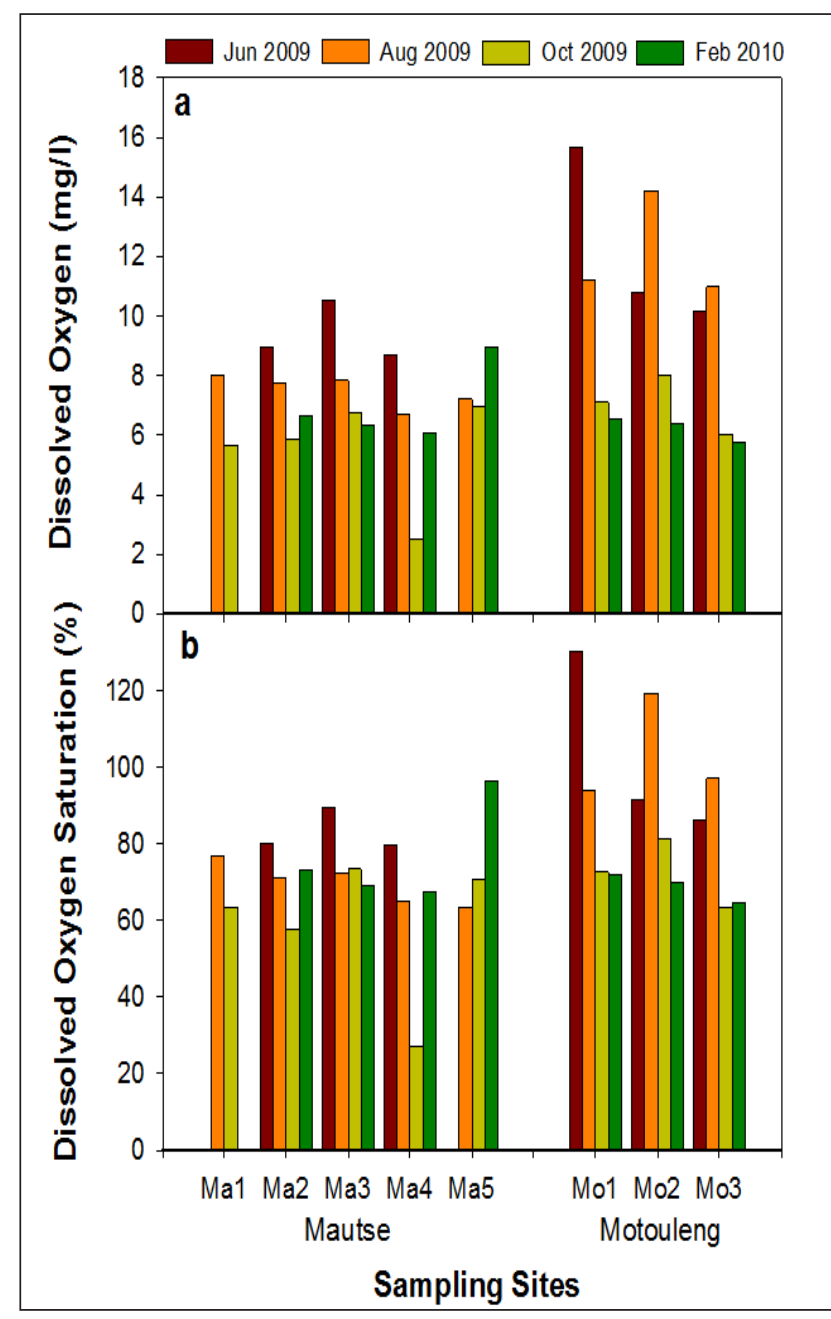

Figure 8

(a) Dissolved oxygen concentrations and (b) percentage saturation at the sampling sites at Mautse and Motouleng for June, August and October 2009, and February 2010

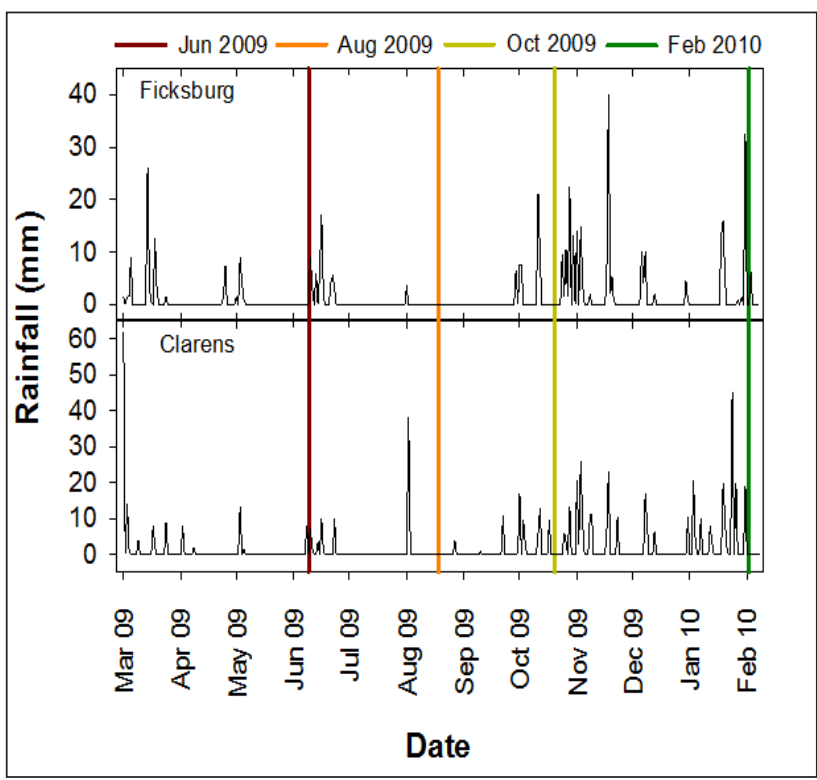

Figure 11

Rainfall at Ficksburg (for Mautse) and Clarens (for Motouleng) from March 2009 to February 2010 (SAWS, n.d.)

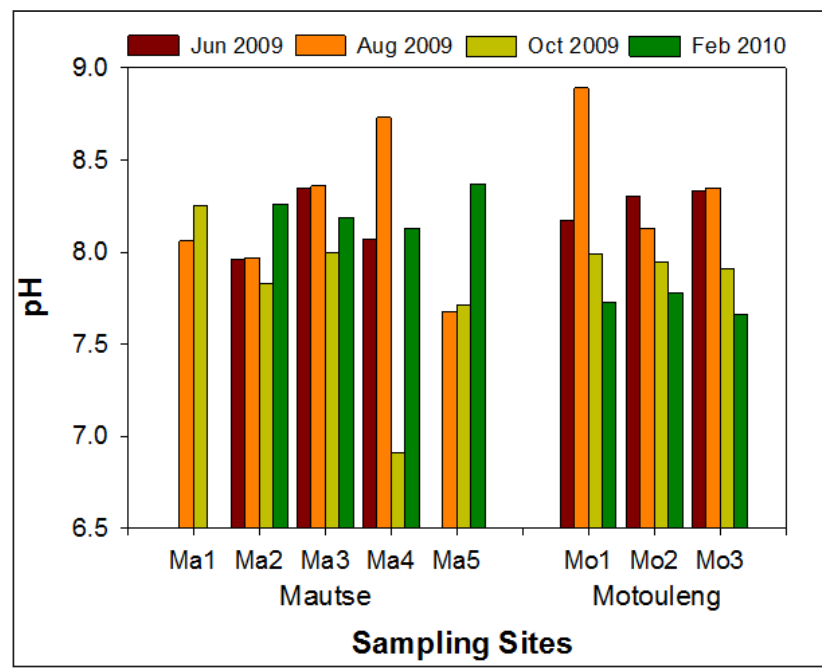

Figure 9

$\mathrm{pH}$ at the sampling sites at Mautse and Motouleng for June, August and October 2009, and February 2010

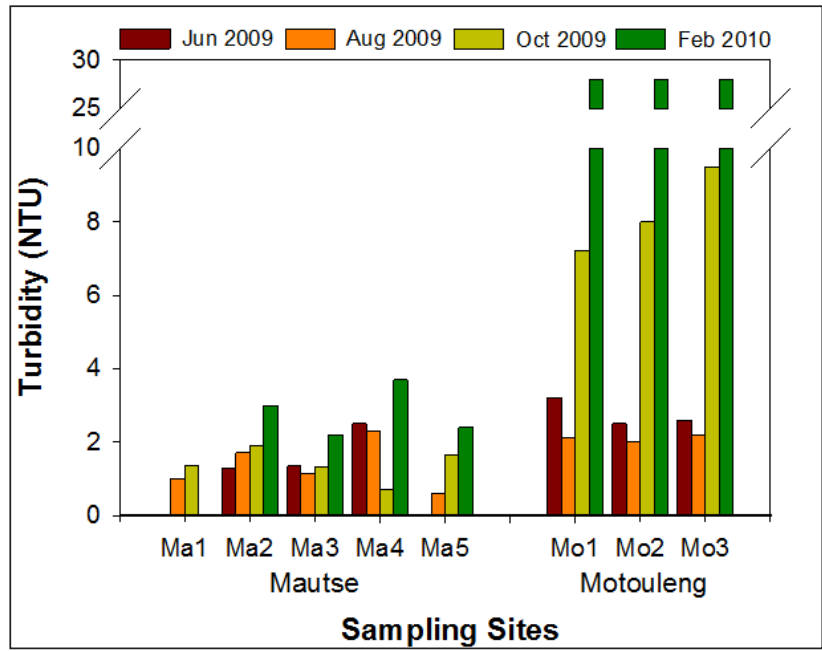

Figure 10

Turbidity at the sampling sites at Mautse and Motouleng for June, August and October 2009, and February 2010

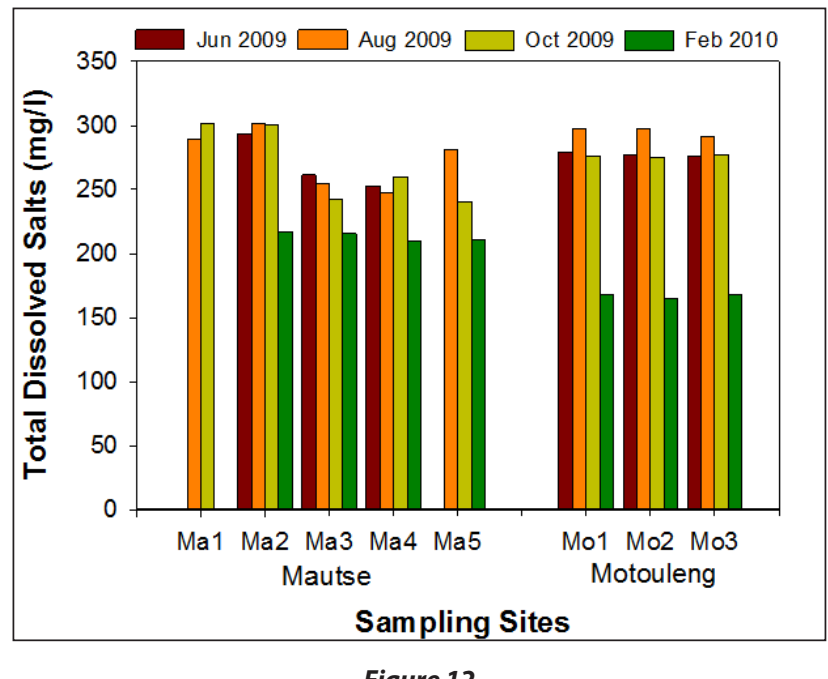

Figure 12

Total dissolved salt concentrations at the sampling sites at Mautse and Motouleng for June, August and October 2009, and February 2010 
human impact was found upstream of these sites. The higher DIP concentrations at sampling sites Ma2 and Ma4 may be as a result of human activities, as Ma2 lies downstream of Tempeleng (MaSC1). It was also observed that at sampling site Ma4 people use the water to clean containers for household use. Dissolved inorganic phosphorous concentrations of $>$ $0.01 \mathrm{mg} / \mathrm{L}$ are seldom found in non-polluted (non-impacted) waters (Dallas and Day, 2004; Horne and Goldman, 1994).

According to the Target Water Quality Range (TWQR) for inorganic phosphorus in the South African Water Quality Guidelines for Aquatic Ecosystems (DWAF, 1996b), the water at both the sites is in poor condition (eutrophic) which could in future result in nuisance algal growth resulting in problems for the environment and the people living at the sites. DIP concentrations at the sites mentioned could, in principle, be taken into consideration when interpreting the turbidity and bacterial indicator results within the RIA context, as there may be some linkages between the parameters and possible human impacts. In spite of the fact that DIP and TP measurements could provide valuable information for extrapolating human activities, both cultural and agricultural, these were excluded from RIA due to the prohibitive costs involved.

The dissolved inorganic nitrogen (DIN) concentrations at both Mautse and Motouleng did not vary as much as the DIP concentrations; Motouleng's DIN (Fig. 14a) also varied less than that of Mautse. The mean DIN concentrations at Motouleng $(0.31 \mathrm{mg} / \mathrm{L})$ was higher than Mautse's $(0.27 \mathrm{mg} / \mathrm{L})$. It was observed that there was a large amount of organic matter present in the sediment (gravel and sandy substrate) of Motouleng, especially upstream of sample site Mo3, that could contribute to the high total nitrogen (TN) (Fig. 14b) concentrations.

Inorganic nitrogen concentrations of unimpacted aerobic surface waters in South Africa are usually below $0.5 \mathrm{mg} / \mathrm{L}$ (DWAF, 1996b). Most of the sampling site means at the two sites (Mautse and Motouleng) fell below the above-mentioned margin, except for Below Tempeleng (Ma2). Based on the data, DIN did not prove inferentially significant and due to this, combined with the high costs involved, was excluded from RIA.

The dissolved organic carbon (DOC; Fig. 15a) concentrations at both Mautse (mean of $2.6 \mathrm{mg} / \mathrm{L}$ ) and Motouleng (mean of $2.5 \mathrm{mg} / \mathrm{L}$ ) were below $5 \mathrm{mg} / \mathrm{L}$, with the highest concentrations in October 2009 (means of $3.7 \mathrm{mg} / \mathrm{L}$ and $3.9 \mathrm{mg} / \mathrm{L}$, respectively). According to DWAF (1996c), the DOC concentration in unpolluted water is usually lower than $5 \mathrm{mg} / \mathrm{L}$. The total organic carbon (TOC; Fig. 15b) concentrations showed the same pattern as the DOC, with the August 2009 concentrations the highest. DOC and TOC are very expensive to analyse and have little extrapolating potential and were therefore not included in RIA.

Based on the chlorophyll- $a$ concentrations, the trophic ranges are either oligotrophic (good) or mesotrophic (fair) for all the sampling sites (Walmsley, 2000; Dodds et al., 1998; Chapman, 1996), but this can deteriorate if chl- $a$ concentrations (and that of algae) increase as temperatures increase, as there are enough nutrients to do so (Reynolds, 1992). Although there is a positive link between chl- $a$ concentrations and turbidity, it did not prove significant at the sites involved and therefore was not considered in developing RIA.

In short, apart from the dissolved inorganic phosphorus concentration, none of the chemical measurements indicated any significant impact. In addition, considering the high costs involved in these analyses, no chemical parameter was included in RIA.

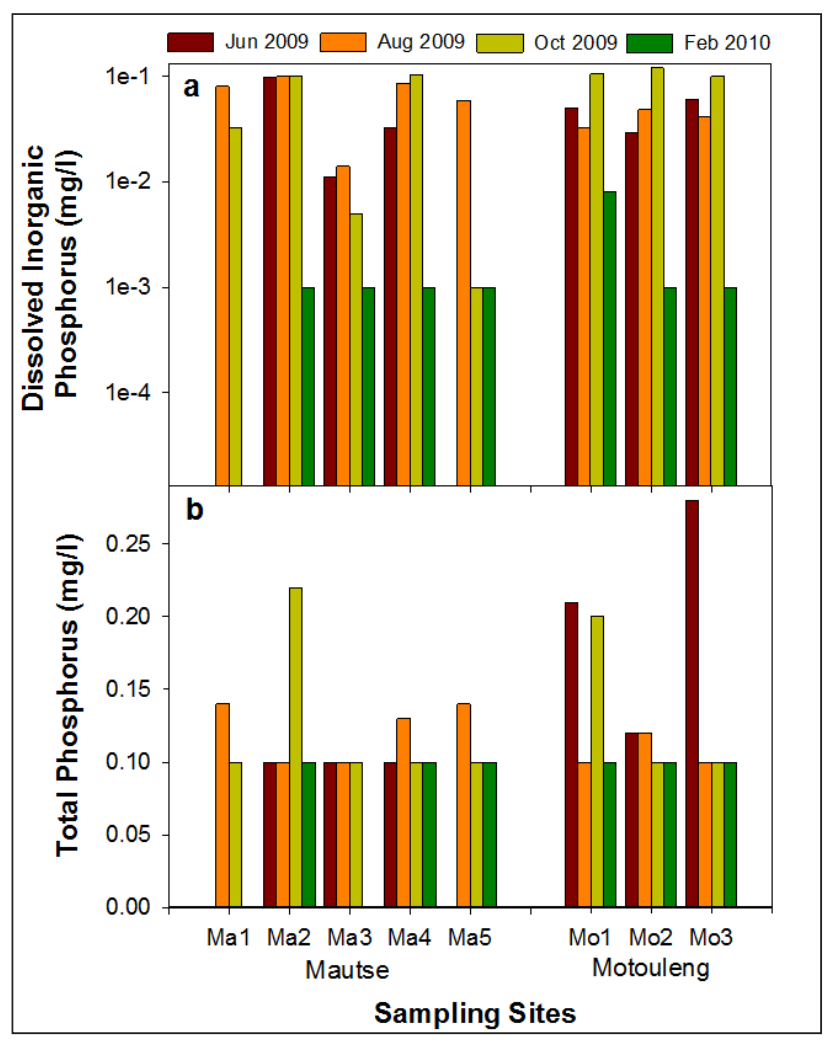

Figure 13

(a) Dissolved inorganic phosphorus (note log on y-axis) and (b) Total phosphorus concentrations at the sampling sites at Mautse and Motouleng for June, August and October 2009, and February 2010

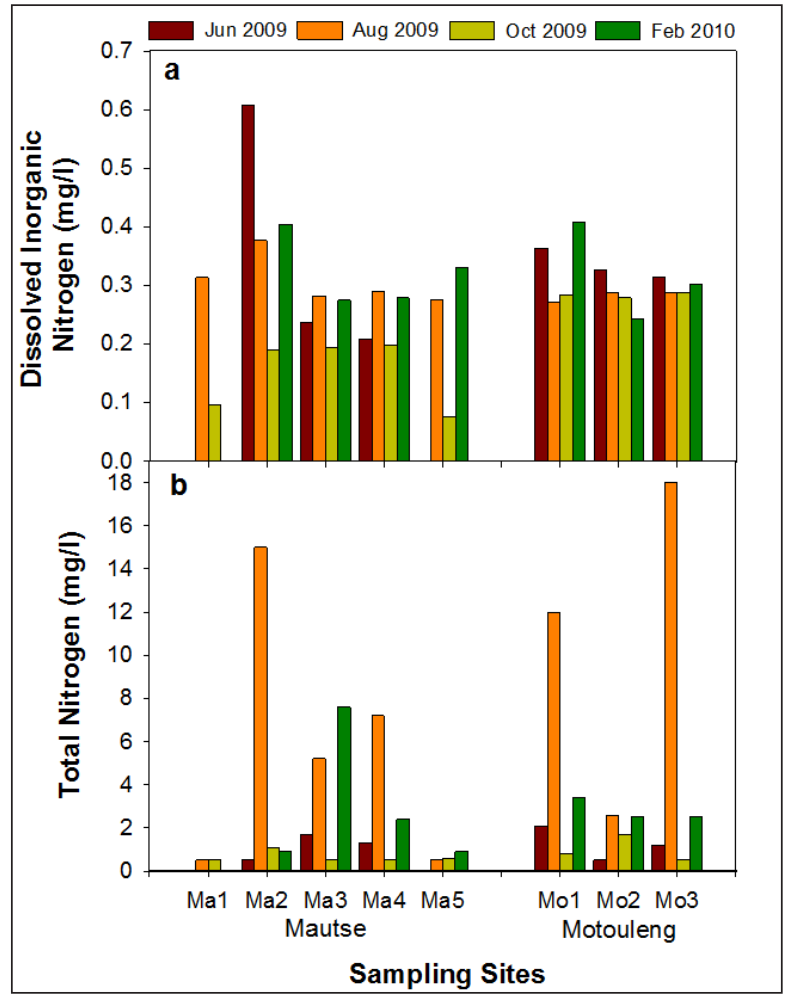

Figure 14

(a) Dissolved inorganic nitrogen and (b) total nitrogen concentrations at the sampling sites at Mautse and Motouleng for June, August and October 2009, and February 2010 


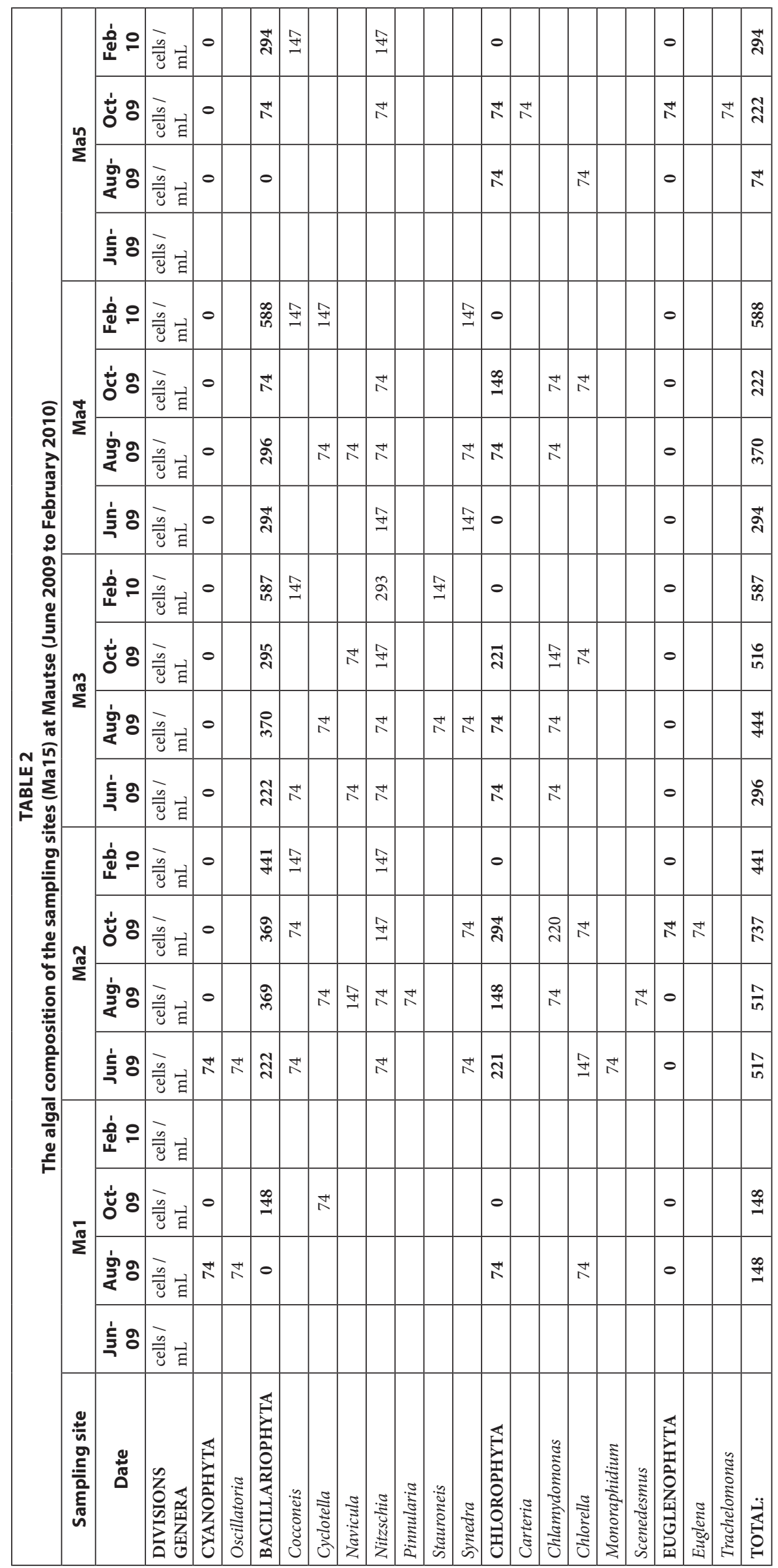




\begin{tabular}{|c|c|c|c|c|c|c|c|c|c|c|c|c|}
\hline \multicolumn{13}{|c|}{$\begin{array}{l}\text { TABLE } 3 \\
\text { The algal composition of the sampling sites (Mo13) at Motouleng (June } 2009 \text { to February 2010) }\end{array}$} \\
\hline \multirow{2}{*}{$\begin{array}{c}\text { Sampling site } \\
\text { Date }\end{array}$} & \multicolumn{4}{|c|}{ Mo1 } & \multicolumn{4}{|c|}{ Mo2 } & \multicolumn{4}{|c|}{ Mo3 } \\
\hline & Jun-09 & $\begin{array}{c}\text { Aug- } \\
09\end{array}$ & Oct-09 & Feb-10 & Jun-09 & $\begin{array}{c}\text { Aug- } \\
09\end{array}$ & Oct-09 & Feb-10 & Jun-09 & $\begin{array}{c}\text { Aug- } \\
09\end{array}$ & Oct-09 & Feb-10 \\
\hline $\begin{array}{l}\text { DIVISIONS } \\
\text { GENERA }\end{array}$ & $\begin{array}{c}\text { cells / } \\
\mathrm{mL}\end{array}$ & $\begin{array}{c}\text { cells / } \\
\mathrm{mL}\end{array}$ & $\begin{array}{c}\text { cells / } \\
\mathrm{mL}\end{array}$ & $\begin{array}{c}\text { cells / } \\
\mathrm{mL}\end{array}$ & $\begin{array}{c}\text { cells / } \\
\mathrm{mL}\end{array}$ & $\begin{array}{c}\text { cells / } \\
\mathrm{mL}\end{array}$ & $\begin{array}{c}\text { cells / } \\
\mathrm{mL}\end{array}$ & $\begin{array}{c}\text { cells / } \\
\mathrm{mL}\end{array}$ & $\begin{array}{c}\text { cells / } \\
\mathrm{mL}\end{array}$ & $\begin{array}{c}\text { cells / } \\
\mathrm{mL}\end{array}$ & $\begin{array}{c}\text { cells / } \\
\text { mL }\end{array}$ & $\begin{array}{c}\text { cells / } \\
\mathrm{mL}\end{array}$ \\
\hline CYANOPHYTA & $\mathbf{0}$ & 74 & $\mathbf{0}$ & $\mathbf{0}$ & $\mathbf{0}$ & $\mathbf{0}$ & $\mathbf{0}$ & $\mathbf{0}$ & $\mathbf{0}$ & $\mathbf{0}$ & $\mathbf{0}$ & $\mathbf{0}$ \\
\hline Oscillatoria & & 74 & & & & & & & & & & \\
\hline BACILLARIOPHYTA & 589 & 587 & 369 & 1,760 & 368 & 515 & 516 & 294 & 368 & 588 & 882 & 880 \\
\hline Cocconeis & & & 74 & 220 & 74 & & & & 74 & & 74 & 440 \\
\hline Cyclotella & 74 & & & 220 & & 74 & 74 & & & & & \\
\hline Cymbella & & & & & 74 & & & & 74 & & 74 & \\
\hline Diatoma & & & & 220 & & & & & & & & \\
\hline Gomphonema & 74 & & & & & & & & & & & \\
\hline Gyrosigma & & & & & & & 74 & & & & & \\
\hline Melosira & 74 & 74 & 74 & 220 & & 74 & 74 & & & 74 & 74 & \\
\hline Navicula & 147 & & & 220 & & 147 & & & & 74 & & \\
\hline Nitzschia & 220 & 513 & 147 & 440 & 220 & 220 & 220 & 147 & 220 & 440 & 513 & 440 \\
\hline Pinnularia & & & 74 & & & & & & & & & \\
\hline Stephanodiscus & & & & 220 & & & & & & & & \\
\hline Synedra & & & & & & & 74 & 147 & & & 147 & \\
\hline CHLOROPHYTA & 74 & 294 & $\mathbf{0}$ & 440 & 148 & 74 & 147 & 147 & 147 & 74 & 0 & 0 \\
\hline Carteria & & 74 & & & & & & & & & & \\
\hline Chlamydomonas & & & & 220 & 74 & 74 & & & & 74 & & \\
\hline Chlorella & 74 & 220 & & & 74 & & 147 & & 147 & & & \\
\hline Monoraphidium & & & & 220 & & & & 147 & & & & \\
\hline EUGLENOPHYTA & $\mathbf{0}$ & $\mathbf{0}$ & $\mathbf{0}$ & $\mathbf{0}$ & $\mathbf{0}$ & 74 & $\mathbf{0}$ & $\mathbf{0}$ & $\mathbf{0}$ & $\mathbf{0}$ & $\mathbf{0}$ & $\mathbf{0}$ \\
\hline Trachelomonas & & & & & & 74 & & & & & & \\
\hline CHRYSOPHYTA & $\mathbf{0}$ & $\mathbf{0}$ & $\mathbf{0}$ & $\mathbf{0}$ & 0 & 74 & $\mathbf{0}$ & $\mathbf{0}$ & 0 & 0 & 0 & $\mathbf{0}$ \\
\hline Mallomonas & & & & & & 74 & & & & & & \\
\hline TOTAL: & 663 & 955 & 369 & 2,200 & 516 & 737 & 663 & 441 & 515 & 662 & 882 & 880 \\
\hline
\end{tabular}

\section{Biological parameters}

Some cyanobacterial species may pose a risk to human health, and algal identification and counts were done to enhance the information obtained from the bacterial counts. The phytoplankton concentrations at Mautse (Table 2) were all below 740 cells/ $\mathrm{mL}$, with the highest concentrations in October 2009 at Ma2. At Motouleng (Table 3), the phytoplankton concentrations were between 360 and 2200 cells/mL, and the mean higher than that of Mautse. Both the sites were dominated by the Bacillariophyte (diatoms) genera, as well as a few Chlorophyte (green algae) genera. Various filament algal species were found on the benthic substrates of sampling sites at both Mautse (especially at Ma2) and Motouleng. No cyanobacteria species that may impact on human health was identified at any of the sites. Consequently, phytoplankton analysis was excluded from RIA. Furthermore, it is a highly specialised field and quite costly, which strengthened the argument against its inclusion in RIA.

Of all the parameters applied, bacterial analysis, specifically E. coli concentrations (Fig. 16), proved the most significant indicator for linking human cultural activity and water quality and therefore played a major role in the development of RIA.

The Department of Water and Sanitation (formerly the Department of Water Affairs and Forestry; DWAF, 1996d) uses faecal coliform bacteria as an indicator of faecal pollution, and E. coli is a highly specific faecal pollution indicator of human and warm-blooded animal origin. At Mautse (Fig. 16), there were very high concentrations of $E$. coli at the sampling sites during October 2009 and February 2010 (rainy season), as well as at sampling sites Ma2 (924 cfu/100 mL) during June 2009 and Ma4 (197 cfu/100 mL) during August 2009 (dry season), indicating possible high levels of faecal pollution at these sampling sites. The mean E. coli concentration at Mautse was $500 \mathrm{cfu} / 100 \mathrm{~mL}$, with the lowest concentrations of E. coli found at Ma1 (Above Tempelang) and Ma5 (Diepsloot). At Motouleng, there was a mean E. coli concentration of about $147 \mathrm{cfu} / 100 \mathrm{~mL}$, and the highest concentrations (> $236 \mathrm{cfu} / 100 \mathrm{~mL}$ ) were found in February 2010, after heavy rains. The highest E. coli concentrations were mostly found at the sites (Mo2 and Mo3) downstream from the cave at Motouleng.

An indirect positive relationship between turbidity and bacterial concentration was found, as both these parameters of water quality are linked to rainfall/high flow conditions. In other words, the higher the rainfall or flow, the higher the turbidity measurement and bacterial concentrations (Garzio-Hadzick et al., 2010). Even though E. coli is not supposed to grow or persist in the environment, it is known to stay vital in sediment for up to 7 days (Akiyama and Savin, 2010). Water-related diseases that are transmitted via the faecal (urine)-oral route (human and animal) and pose health risks include: amoebic dysentery (Entamoeba histolytica), campylobacteriosis (Campylobacter jejuni), cholera (Vibrio cholerae), cryptosporidiosis 


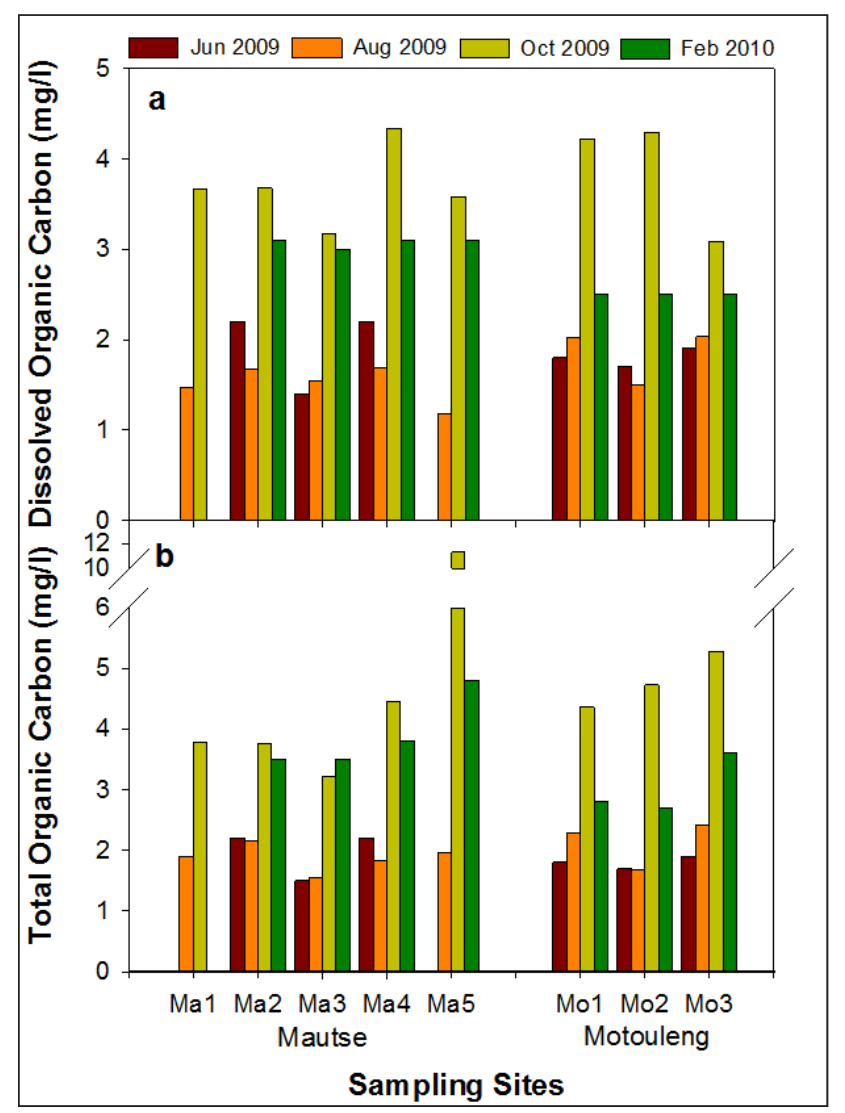

Figure 15

(a) Dissolved organic carbon and (b) total organic carbon concentrations at the sampling sites at Mautse and Motouleng for June, August and October 2009, and February 2010

(Cryptosporidium parvum), gastroenteritis (Salmonella or E. coli), giardiasis (Giardia lambia), hepatitis A and E, Weil's disease (Leptospira interrogans), poliomyelitis and typhoid fever (Salmonella typhi) (Kempster, 2003).

No quality ranges for full body contact were found for E. coli, apart from recreational use (swimming), for which 0-130 cfu/100 mL poses a low risk for gastrointestinal illness (0.8\% of swimmers; DWAF, 1996d). As the E. coli concentrations increase, so does the risk of illness. With 130-200 cfu/100 mL there is a slight risk and with $200-400 \mathrm{cfu} / 100 \mathrm{~mL}$ some risk of illness. When the E. coli concentrations increase above $400 \mathrm{cfu} / 100 \mathrm{~mL}$, smaller amounts of water need to be ingested to cause illness. These sites are used for baptism and cleansing rituals thus the target range for recreational use can be viewed as relevant. However, WRC (1998) suggests that faecal coliform concentrations (this includes E. coli) from $10-100 \mathrm{cfu} / 100 \mathrm{~mL}$ slightly increased the risk of infection when bathing and the possibility of infection at above $100 \mathrm{cfu} / 100 \mathrm{~mL}$ exists. For drinking water, the infection probability starts at $1 \mathrm{cfu} / 100 \mathrm{~mL}$, especially with sensitive or immune-compromised/suppressed individuals.

Throughout the valley of Mautse, the use of raw water by the pilgrims was documented by the researchers for cooking, beer making and other domestic uses such as washing utensils. The research has found that many pilgrims were, to some extent, aware of the poor water quality condition of specific water bodies such as Tempeleng and the need to use alternative water sources or to boil the water. However, this knowledge is not universally shared amongst all pilgrims due to the highly fluid nature of the community, with newcomers adding to the pilgrim community constantly. It is these novice pilgrims that are most likely to be misled by a possible 'masking effect' (Vos and Cawood, 2010), based on the fallacy that 'clear, flowing water is clean water', which might increase the potential for bacterial infection, especially at Mautse. As mentioned before, because of the predominantly bedrock substrate, water remains clear, in spite of the high concentrations of $E$. coli. This could create the illusion that the water is safe for drinking or even cooking purposes.

The risk to human health when people use these sites indiscriminately is evident. Should RIA point towards human health risk, as in the aforementioned cases, formal interventions would not be possible as these sites fall outside the formal sector, but basic and low-cost informal interventions such as teaching site users, and in particular novices, to avoid certain bodies of water or boiling the water may mitigate the human health risk.

\section{CONCLUSION}

Whereas declared provincial and national heritage sites are subject to management protocols, informal sites are vulnerable to unfettered human interference. Should informal sites in terms of the water quality become degraded to such an extent that all human activities are prohibited due to public health concerns, the effect on the integrity and sustainability of the cultural heritage involved will be devastating. Cultural practices associated with sacred sites are meaningful because they are embedded in those spaces. Without the specific sacred space, the practice will cease to exist and potentially important heritage will be lost.

With the possibility of many more informal heritage sites existing in South Africa (and worldwide), and given expensive and time-consuming formal declaration procedures, there is a definite need for specialised and efficient tools to monitor the health of informal sites. RIA was developed as a basic and cost-effective model for intervention at and management of informal heritage sites. It must be emphasised that the model is still in its inception phase and will require significant refinement during and after field testing and implementation at similar sites elsewhere. What can be said with relative certainty at this point in time is that the parameters that constitute RIA proved to be sources of rich data for the extrapolation of the integrity of Mautse and Motouleng. Hopefully, RIA will prove useful in the continued monitoring of these and other informal heritage sites. As yet, the RIA model is still untested, but the authors consider it to be sufficiently developed to provide a wealth of data in field testing. The application thereof to the same study sites and other informal heritage sites with similar cultural activity for the purpose of comparison is the expected next stage in the overarching research project and will form the basis of future research articles and policy recommendations in the heritage sector.

Finally, other aspects of water quality, such as oxygen concentration, temperature and the TDS, nutrient and bacterial concentration, could even be included as part of the regular monitoring of a formally declared heritage site or in rare cases where a comprehensive bio-cultural screening is feasible and specifically warranted for an informal heritage site. Depending on the results of these analyses and contextual information, HIA, MIRAI and FRAI may also come into play should resources be available.

\section{ACKNOWLEDGEMENTS}

We would like to thank the National Heritage Council and the Strategic Academic Cluster of the University of the Free State: Water Management in Water-Scarce Areas for the financial support of this collaboration. 


\section{REFERENCES}

ALLANSON BR (1995) An Introduction to the management of inland water ecosystems in South Africa. WRC Report No. TT 72/95. Water Research Commission, Pretoria. 77 pp.

AKIYAMA T and SAVIN MC (2010) Populations of antibiotic-resistant coliform bacteria change rapidly in a wastewater effluent dominated stream. Sci. Total Environ. 408 (24) 6192-6201. http://dx.doi. org/10.1016/j.scitotenv.2010.08.055

AMERICAN PUBLIC HEALTH ASSOCIATION (APHA) (2005) Standard Methods for the Examination of Water and Wastewater (21st edn.). In: Eaton AD, Clesceri LS, Rice EW and Greenberg AE (eds). American Public Health Association / American Water Works Association / Water Environment Federation, Washington DC. 4-152-4-153.

BAILEY I (2010) Water related microbial disease guidelines. Vol. 3: How big is the problem? Health Impact Assessment. Joint Water Research Commission and Umgeni Water report. WRC Report No. TT429/10. Water Research Commission, Pretoria. 75 pp.

BATE GC, ADAMS JB and VAN DER MOLEN JS (2002) Diatoms as Indicators of Water Quality in South African River Systems. WRC Report No. 814/1/02. Water Research Commission, Pretoria. 164 pp

CAWOOD S (ed.) (2010) NHC Project Report - Oral Histories and the Cultural Uses of Clay at Sacred Sites in the Free State. Centre for Africa Studies, University of the Free State. 267 pp.

CHAPMAN D (ed.) (1996) Water Quality Assessments: A Guide to the Use of Biota, Sediments and Water in Environmental Monitoring (2nd edn.) UNESCO/WHO/UNEP EandFN Spon, London. 651 pp. URL: http:// www.who.int/water_sanitation_health/en/ (Accessed 15 May 2008).

CHUTTER FM (1994) The rapid biological assessment of stream and river water quality by means of the macroinvertebrate community in South Africa. In: Uys MC (ed.) Classification of rivers, and environmental health indicators. Proceeding of a joint South African/Australian workshop. February 7-14 1994, Cape Town, South Africa. WRC Report No. TT63/94. Water Research Commission, Pretoria. 419 pp.

CHUTTER FM (1972) An empirical biotic index of the quality of water in South African streams and rivers. Water Res. 6 (1) 19-30. http:// dx.doi.org/10.1016/0043-1354(72)90170-4

DALLAS HF and DAY JA (2004) The effect of water quality variables on aquatic ecosystems: a review. WRC Report No. TT 224/04. Water Research Commission, Pretoria. 222 pp.

DAVIES B and DAY J (1998) Vanishing Waters. University of Cape Town Press, Cape Town. 487 pp.

DICKENS CWS and GRAHAM PM (1998) Biomonitoring for effective management of wastewater discharges and the health of the river environment. Aquat. Ecosyst. Health Manag. 1 (2) 199-217. http:// dx.doi.org/10.1016/s1463-4988(98)00023-2

DODDS WK, JONES JR and WELCH EB (1998) Suggested classification of stream trophic state: distributions of temperate stream types by chlorophyll, total nitrogen and phosphorus. Water Res. 32 (5) 1455-1462. http://dx.doi.org/10.1016/S0043-1354(97)00370-9

DWAF (Department of Water Affairs and Forestry, South Africa) (1996a) South African Water Quality Guidelines. Volume 6. Agricultural Water Use: Aquaculture (2nd edn.; 1st issue). 194 pp.

DWAF (Department of Water Affairs and Forestry, South Africa) (1996b) South African Water Quality Guidelines. Volume 7. Aquatic Environment (1st edn.; 1st issue). 159 pp.

DWAF (Department of Water Affairs and Forestry, South Africa) (1996c) South African Water Quality Guidelines. Volume 1. Domestic Water Use (2nd edn.; 1st issue). 197 pp.

DWAF (Department of Water Affairs and Forestry, South Africa) (1996d) South African Water Quality Guidelines. Volume 2. Recreational Use (2nd edn.; 1st issue). $88 \mathrm{pp}$.

DWS (Department of Water and Sanitation, South Africa) (2016) River Eco-status Monitoring Programme. URL: https://www.dwa.gov.za/ IWQS/rhp/default.aspx (Accessed 18 May 2016).

GARZIO-HADZICK A, SHELTON DR, HILL RL, PACHEPSKY YA, GUBER AK and ROWLAND R (2010) Survival of manure-borne E. coli in streambed sediment: effects of temperature and sediment properties. Water Res. 44 (9) 2753-2762. http://dx.doi.org/10.1016/j. watres.2010.02.011

GOOGLE MAPS (2015) URL: http://maps.google.com/ (Accessed 15 December 2015).
HORNE AJ and GOLDMAN CR (1994) Limnology (2nd edn.). McGraw-Hill, Inc. Singapore. 576 pp.

IDEXX LABORATORIES, INC. (IDEXX) (2015) Colilert-18. URL: https://www.idexx.com/resource-library/water/colilert-18-procedure-en.pdf (Accessed 18 May 2016).

KEMPSTER PL (2003) Management of water-related microbial diseases. Vol 1: What is the problem? Disease characteristics. Joint Water Research Commission and Department of Water Affairs and Forestry report. WRC Report No. TT175/03. Water Research Commission, Pretoria.

KLEYNHANS CJ (2007) Module D: Fish Response Assessment Index in River EcoClassification: Manual for EcoStatus Determination (version 2). Joint Water Research Commission and Department of Water Affairs and Forestry report. WRC Report No. TT330/08. Water Research Commission, Pretoria, South Africa.

KLEYNHANS CJ, LOUW MD and GRAHAM M (2009) Module G: EcoClassification and EcoStatus determination in River EcoClassification: Index of Habitat Integrity (Section 1, Technical Manual). Joint Water Research Commission and Department of Water Affairs and Forestry report. WRC Report No. TT377/09. Water Research Commission, Pretoria.

KLEYNHANS CJ, LOUW M.D, THIRION C, ROSSOUW NJ and ROWNTREE K (2005) River EcoClassification: Manual for EcoStatus determination (Version 1). Joint Water Research Commission and Department of Water Affairs and Forestry report. WRC Report No. KV168/05. Water Research Commission, Pretoria.

KLEYNHANS CJ, MACKENZIE J and LOUW MD (2007) Module F: Riparian Vegetation Response Assessment Index in River EcoClassification: Manual for EcoStatus Determination (Version 2). Joint Water Research Commission and Department of Water Affairs and Forestry report. WRC Report No. TT333/08. Water Research Commission, Pretoria.

REYNOLDS CS (1992) Chapter 9: Algae. In: Calow P and Petts GE (eds.) The Rivers Handbook: Hydrological and Ecological Principles. Volume 1. Blackwell Scientific Publication, Oxford. 195-215.

ROOS JC and PIETERSE AJH (1995) Salinity and dissolved substances in the Vaal River at Balkfontein, South Africa. Hydrobiologia 306 (1) 41-51. http://dx.doi.org/10.1007/BF00007857

ROWNTREE KM (2013) Module B: Geomorphology Driver Assessment Index in River EcoClassification: Manual for EcoStatus Determination (Version 2). Joint Water Research Commission and Department of Water Affairs and Forestry report. WRC Report No. TT551/13. Water Research Commission, Pretoria.

RSA (Republic of South Africa) (1999) National Heritage Resources Act Act No. 25 of 1999. Republic of South Africa. Government Gazette No. 19974. Government Printer, Pretoria/Cape Town.

SARTORY DP and GROBBELAAR JU (1984) Extraction of chlorophyll-a from freshwater phytoplankton for spectrophotometric analysis. Hydrobiologia 114 (3) 177-187. http://dx.doi.org/10.1007/ BF00031869

SAWS (South African Weather Service) (n.d.) Rainfall data. URL: http:// www. WeatherSA.co.za (Accessed 10 February 2010).

THIRION C (2007) Module E: Macroinvertebrate Response Assessment Index in River EcoClassification: Manual for EcoStatus Determination (Version 2). Joint Water Research Commission and Department of Water Affairs and Forestry report. WRC Report No. TT332/08. Water Research Commission, Pretoria.

VOS AT and CAWOOD S (2010) The impact of water quality on informally declared heritage sites: a preliminary study. Water SA 36 (2) 185-192.

WALLING DE and WEBB BW (1992) Chapter 3: Water Quality I. Physical Characteristics. In: Calow P and Petts GE (eds.). The Rivers Handbook: Hydrological and Ecological Principles Volume 1. Blackwell Scientific Publication, Oxford. 48-72.

WALMSLEY RD (2000) Perspectives in Eutrophication of Surface Waters: Policy/Research Needs in South Africa. WRC Report No. KV129/00. Water Research Commission, Pretoria. 60 pp.

WRC (Water Research Commission) (1998) Quality of Domestic Water Guideline. Volume 1. Assessment Guide (2nd edn). Department of Water Affairs and Forestry/ Department of Health/ Water Research Commission. WRC Report No. TT101/98. Water Research Commission, Pretoria. 104 pp.

WETZEL RG and LIKENS GE (1991) Limnological Analyses. SpringerVerlag Inc., New York. 467 pp. 